TOXIC EFFECTS AND BROTOWALI TERATOGENIC EXTRACT (Tinospora crispa L.) ON REPRODUCTIVE SYSTEM AND EMBRYOS MICE (Mus musculus L. Swiss Webster).

\title{
EFEK TOKSIT DAN TERATOGENIK EKSTRAK BROTOWALI (Tinospora crispa L.) TERHADAP SISTEM REPRODUKSI DAN EMBRIO MENCIT (Mus musculus L. Swiss Webster)
}

\section{Rina Widiana ${ }^{1 *}$ dan Ramadhan Sumarmin ${ }^{2}$}

${ }^{1}$ Program Studi Pendidikan Biologi STKIP PGRI Sumatera Barat.

Jl. Gunung Pangilun Padang, Kota Padang, Sumatera Barat, Indonesia. Telp./Fax. (0751) 7053731/ (0751) 7053826. Email: rinaroesdi68@ gmail.com

${ }^{2}$ Jurusan Biologi FMIPA Universitas Negri Padang

Jl. Prof. Dr. Hamka Air Tawar Kota Padang, Sumatera Barat, Indonesia Telp./Fax. (0751) 7053902/ (0751) 7055628.

Manuskript diterima: 23 Mei 2016. Revisi disetujui: 28 Juni 2016.

\begin{abstract}
Tinospora crispa (brotowali) is known as a medicine plant in Indonesia. Brotowali have bioactive compounds which useful for medicine. It can found at all part of this plant. Tinospora crispa stem has bitter kolumbin, alcaloid and glicoside. Alcaloid is antiproliferative. This antiproliferative can reduce the amount of oosit which is produced and decrease the amount of oosit which is ovulated so it affects the reproduction performance of mice. This research has purpose to know the effect toxic and teratogenic of Tinospora crispa extract to the reproduction system and embryo of mice.This research is experimantal research used female mice (Mus musculus L.) as many as 24 female mice. This research used completely randomized designed which are divided into 4 treatmentsand 6 replication. The treatments given is brotowali extractwith variety of dosages, they are: $A$ iscontrol,B treatment $\left(5 \times 10^{-2}\right), C\left(6 \times 10^{-2}\right)$ andD $\left(7 \times 10^{-2}\right) \mathrm{gram} / \mathrm{mice}$.The parameter observed is the amount of corpus Luteum, implantations, resorptions, died fetus and alive fetus. The data which is measured by Analisis of Varians then by DNMRT. The result shows that brotowali extract to the female mice with 0 day till $16^{\text {th }}$ day pregnance has significantly higher $(p<0,05)$ to the amount of corpus Luteum, the alive fetus, the died fetus and resorption. While, the amount of implantation has not significantly. Thus, it can be concluded that brotowali extract for the female mice pregnant have embryotoxic and fetotoxic effects.
\end{abstract}

Keywords: Tinospora crispa L., alcaloid, saponin, embryotoxic and teratogenic

\section{ABSTRAK}

Tinospora crispa (brotowali) dikenal sebagai tumbuhan obat di Indonesia. Brotowali memiliki senyawa bioaktif yang bermanfaat untuk obat. Hal ini dapat 
ditemukan di semua bagian tanaman ini. Batang Tinospora crispa mengandung kolumbin, zat pahit, alkaloid dan glicosida. Alkaloid merupakan zat antiproliferatif, dimana zat antiproliferatif ini dapat mengurangi jumlah oosit yang dihasilkan dan mengurangi jumlah oosit yang mengalami ovulasi sehingga mempengaruhi penampilan reproduksi mencit. Penelitian ini bertujuan untuk mengetahui efek toksik dan teratogenik ekstrak Tinospora crispa pada sistem reproduksi dan embrio tikus. Penelitian ini merupakan penelitian eksperimen dengan menggunakan mencit betina (Mus musculus L.) sebanyak 24 ekor. Penelitian memakai rancangan acak lengkap dengan empat perlakuan dan enam ulangan. Perlakuan yang diberikan adalah ekstrak brotowali dengan berbagai dosis, yaitu: A adalah kontrol, perlakuan B $\left(5 \times 10^{-2}\right), \mathrm{C}\left(6 \times 10^{-2}\right)$ dan D $\left(7 \times 10^{-2}\right)$ $\mathrm{g} /$ mencit. Parameter yang diamati adalah jumlah korpus luteum, implantasi, embrio resorpsi, janin mati dan janin hidup. Data dianalisis dengan Analisis Varians dan uji lanjut DNMRT pada taraf $\alpha$ 5\%. Hasil penelitian menunjukkan bahwa ekstrak brotowali berpengaruh nyata terhadap jumlah korpus luteum, janin hidup, janin mati dan embrio resorpsi mencit dengan 0 sampai 16 hari kehamilan. Sementara, terhadap jumlah implantasi berpengaruh tidak nyata, sehingga dapat disimpulkan bahwa ekstrak brotowali memiliki efek embriotoksik dan fetotoksik terhadap mencit betina hamil.

Kata kunci: Tinospora crispa L., alkaloid, saponin, embryotoksik dan teratogenik

\section{PENDAHULUAN}

Salah satu cara program keluarga berencana yang banyak digunakan masyarakat Indonesia adalah kontrasepsi oral, yaitu dengan mengkonsumsi pil yang mengandung hormon estrogen dan progesteron sintetis atau kombinasi keduanya. Hal ini disebabkan biayanya lebih murah dibanding dengan cara-cara yang lain. Tetapi disisi lain, kontrasepsi oral dengan hormon sintetis sering menimbulkan efek samping yang tidak diharapkan, seperti nausea, hipertensi, trombosis, radang hati dan lain-lain, yang merupakan salah satu kelemahan kontrasepsi oral (Lukman, 1979 dalam Erlina, 1981). Sebagai upaya menghindari efek samping dari penggunaan kontrasepsi oral dengan bahan sintetis dapat digunakan kontrasepsi dengan bahan alami yang berasal dari tumbuhan obat. Tumbuhan obat menghasilkan senyawa aktif biologi yang dapat digunakan sebagai bahan antifertilitas. Senyawa tersebut umumnya termasuk golongan steroid, isoflavonoid, triterpenoid dan xanton (Farnsworth dkk., 1975; Chattopadhyay dkk., 1984 dan Adnan, 1992).

Salah satu dari tumbuhan yang mungkin dikembangkan sebagai bahan untuk kontrasepsi alami adalah brotowali (Tinospora crispa L.). Brotowali 
(Tinospora crispa L.) merupakan tumbuhan obat herbal dari familia Menispermaceae. Brotowali (Tinospora crispa L.) merupakan tumbuhan perdu merambat dengan panjang mencapai 2,5 meter atau lebih. Batang Brotowali kecil, berbintil-bintil rapat dan rasanya pahit (Kresnadi, 2003). Daun dan batang brotowali mengandung alkaloid, saponin dan tannin, sedangkan batangnya mengandung flavanoid (Supriadi, 2001). Batang Tinospora crispa L. mengandung senyawa alkaloid 2,22 \%, barberin, zat pahit, kolumbin, glukosid dan pikokarotin (Dweck, 2006). Studi pustaka terhadap kandungan kimia jenis-jenis tumbuhan dari keluarga Menispermaceae menunjukkan adanya beberapa macam alkaloid, yaitu berberina, palmatina, kolumbamina, yatrorrhiza.

Flavanoid merupakan senyawa alam yang mengandung 15 atom karbon sebagai rangka dasarnya. Flavanoid termasuk dalam golongan fitoestrogen yaitu sumber estrogen yang berasal dari tanaman yang merupakan senyawa non steroidal dan memiliki aktivitas estrogenik (Juneja dkk., 2001 dalam Wurlina, 2003). Alkaloid didefinisikan oleh Winterstein dan Trier sebagai senyawasenyawa yang bersifat basa, mengandung atom nitrogen berasal dari tumbuhan dan hewan. Alkaloid merupakan golongan fitoestrogen. Alkaloid memiliki efek hormonal khususnya efek estrogenik. Senyawa saponin merupakan larutan berbuih dan merupakan steroid atau glikosidatriterpenoid. Efek negatif dari saponin pada reproduksi hewan diketahui sebagai abortivum, menghambat pembentukan zigot dan anti implantasi (de Padua,1978 dalam Rusmiati, 2010). Saponin bersifat sitotoksik terhadap sel terutama yang sedang mengalami perkembangan, seperti pada saat oogenesis (Nurhuda dkk., 1995 dalam Nurliani, 2007).

Sifat estrogenik dari senyawa yang dikandung brotowali dapat mempengaruhi sistem hormonal serta diduga menyebabkan gangguan pada proses ovulasi dan fertilisasi. Harborne (1987 dalam Sumarmin, 2001) menyatakan adanya alkaloid, triterpenoid dan terpenoid pada suatu ekstrak dapat menyebabkan terjadinya interpensi ekstrak pada poros hipotalamus, hipofisis dan gonad sehingga menekan sekresi FSH dan LH. Sebagai akibat kurangnya FSH dan LH pada awal siklus menyebabkan dominasi hormon estrogen meningkat tajam. Selanjutnya kondisi ini akan menunda siklus estrus atau memperpanjang siklus 
estrus. Berdasarkan hasil penelitian Widiana dan Sumarmin (2014) didapatkan bahwa pemberian ekstrak brotowali (Tinospora crispa L.) pada mencit (Mus musculus L.) dapat memperpanjang siklus estrus hingga \pm 13 hari dan dan tidak mempengaruhi karakter morfologi ovarium, sehingga dapat dijadikan alternatif bahan kontrasepsi alami.

Selain flavonoid, brotowali mengandung alkaloid yang juga bersifat estrogenik. Selain bersifat estrogenik, alkaloid yang dikandung brotowali juga memiliki sifat toksik dan antiproliferatif terhadap sel kanker (Chantong, 2008). Sifat antiproliferatif dari alkaloid ini diperkirakan akan dapat menghambat proses oogenesis dari mencit, karena pada proses oogenesis juga berlangsung proses proliferasi. Selanjutnya bila proses proliferasi dapat dihambat, maka produksi ovum dan ovulasi akan terhambat, sehingga secara tidak langsung akan menperkecil peluang terjadinya konsepsi dan kehamilan seperti yang diharapkan dari program keluarga berencana. Senyawa alkaloid, selain memperlihatkan sifat antiproliferasi juga memiliki sifat embriotoksit dan teratogenik, seperti yang dilaporkan Sabri (2007) alkaloid dapat menyebabkan meningkatnya kehilangan praimplantasi secara nyata, jumlah implantasi dan jumlah fetus hidup menurun secara nyata serta bersifat antifertilitas. Keadaan ini menggambarkan terdapat gangguan pada saat terjadi sumbat vagina sehingga diduga dapat mempengaruhi sistem reproduksi dan embrio.

Efek terhadap embrio yang dikandung dapat dilihat melalui pengamatan terhadap penampilan reproduksi dari mencit. Menurut (Taylor, 1986) karakter penampilan reproduksi meliputi jumlah implantasi, jumlah fetus hidup, jumlah fetus mati, jumlah fetus abnormal, jumlah korpus Luteum dan embrioresorpsi. Soesanto (1988) menyatakan jumlah anak sekelahiran adalah jumlah total anak yang hidup maupun anak yang mati pada waktu dilahirkan. Jumlah anak sekelahiran berkisar 6-15 ekor per kelahiran. Besarnya jumlah anak sekelahiran dipengaruhi oleh bangsa hewan, umur induk, musim kelahiran, makanan dan kondisi lingkungan. Faktor-faktor lingkungan yang mempengaruhi jumlah anak sekelahiran antara lain kualitas dan kuantitas pakan yang diberikan pada induk, musim kawin, jumlah sel telur yang dihasilkan serta tingkat kematian embrio (Toelihere, 1979). 
Menurut Yatim (1994) implantasi adalah perlekatan dan penetrasi berikutnya oleh telur yang telah dibuahi (pada tahap blatosista) di dinding rahim, yang dimulai dari 5 sampai 7 hari pembuahan. Korpus Luteum merupakan sisa folikel de Graff yang terdapat dalam ovarium setelah terjadi ovulasi. Ovulasi yaitu proses pecahnya folikel de Graff dan dilepaskannya ovum disertai sel-sel granulosa yang membungkusnya, sel granulosa yang tersusun secara radial sehingga disebut dengan corona radiata. Setelah ovulasi, sel-sel folikel de Graff yang tinggal dalam ovarium menjadi korpus Luteum (badan kuning), karena sel granulosanya mengandung pigmen yang berwarna kuning disebut lipokrom. Embrio resorpsi adalah embrio yang sudah terimplantasi tetapi tidak dapat berkembang ke tahap selanjutnya karena mengalami resorpsi (Harbinson, 1980 dalam Setyawati, 2006).

Melihat dari beragamnya kandungan bahan aktif dari brotowali yang berpotensi sebagai bahan kontrasepsi sehingga perlu dilakukan penelitian lebih lanjut terhadap kriteria-kriteria lain yang harus dipenuhi suatu bahan untuk bisa dijadikan bahan kontasepsi alami yang aman dan potensial serta kemungkinan adanya efek toksit dan teratogenik yang ditimbulkan pada sistem reproduksi dan embrio yang dikandung. Berdasarkan uraian di atas, maka telah dilakukan penelitian dengan tujuan untuk melihat Efek toksik dan teratogenik ekstrak brotowali (Tinospora crispa L.) terhadap sistem reproduksi dan embio mencit (Mus musculus L.).

\section{BAHAN DAN METODE}

\section{Waktu dan Tempat}

Penelitian ini dilaksanakan pada bulan Maret 2014 di Laboratorium Zoologi Jurusan Biologi FMIPA Univesitas Negeri Padang.

\section{Rancangan Penelitian}

Rancangan yang digunakan dalam penelitian ini adalah Rancangan Acak Lengkap (RAL) dengan 4 perlakuan dan 6 ulangan. Adapun perlakuan yang diberikan adalah: A) Kontrol (pemberian CMC 5\%), B) ekstrak brotowali dosis $\left.0,05 \mathrm{mgbb}^{-1}, \mathrm{C}\right)$ ekstrak brotowali dosis $0,06 \mathrm{mgbb}^{-1}$ dan D) ekstrak brotowali dosis $0,07 \mathrm{mgbb}^{-1}$. 


\section{Penyediaan Hewan Uji}

Hewan uji yang digunakan adalah mencit (Mus musculus L. Swiss Webster) betina dewasa umur 8-10 minggu dengan berat badan 20-30 gram sebanyak 24 ekor.

\section{Pembuatan Ekstrak Brotowali (Tinospora crispa L.)}

Potongan batang brotowali kering ditimbang sebanyak $250 \mathrm{~g}$ dihaluskan dan direndam dalam metanol sebanyak $500 \mathrm{ml}$ selama 72 jam. Selanjutnya disaring dan diuapkan dalam water bath sampai didapatkan ekstrak pekat. Untuk pemberian pada hewan percobaan ekstrak padat diemulsikan dan diencerkan dengan larutan CMC 5\% sesuai perlakuan.

\section{Penentuan Dosis dan Pemberian Ekstrak}

Penentuan dosis berdasar dosis kapsul brotowali yang sudah jadi, dosis kapsul untuk manusia dikonversi ke dosis untuk mencit (Laurence dan Bachrach, 1964), sehingga didapat dosis untuk mencit 0,0036 mg. Pemberian ekstrak brotowali dilakukan setiap pagi hari pada jam 10.00 WIB. Pemberian dilakukan secara oral menggunakan jarum gavage dengan volume 0,5 cc. Pemberian ekstrak pada hewan uji berlangsung setiap hari selama 16 hari dan dimulai dari 0 hari kebuntingan.

Mencit betina dewasa sedang estrus dikawinkan dengan seekor mencit jantan pada pukul 18.00 WIB dengan perbandingan 1:4. Keesokan harinya pada pukul 06.30 WIB diamati keberadaan sumbat vagina sebagai tanda kopulasi telah terjadi dan dinyatakan sebagai kehamilan 0 hari (Taylor, 1986). Jika sumbat vagina tidak terlihat, maka dibuat apusan vagina untuk melihat ada tidaknya sperma, jika terdapat sperma berarti sudah terjadi kopulasi, serta dinyatakan sebagai kehamilan 0 hari. Selanjutnya mencit dari kelompok perlakuan dan kelompok kontrol dibunuh dengan cara dislokasi leher pada umur kehamilan 18 hari. Kemudian dilakukan pembedahan pada bagian abdominal, lalu dipisah semua organ reproduksi. Setelah pembedahan, dilakukan pengamatan meliputi korpus luteum, jumlah implantasi, jumlah fetus hidup, jumlah fetus mati, jumlah fetus abnormal, embrio yang diresorpsi. 


\section{Analisis Data}

Data yang dianalis dengan Analisis Varian (ANAVA), dan dilanjutkan dengan uji lanjut Duncan New Multiple Range Test (DNMRT) pada taraf $\alpha 5 \%$.

\section{HASIL}

Hasil pengamatan jumlah korpus luteum, jumlah implantasi, jumlah fetus hidup dan mati serta jumlah embrio resorpsi dapat dilihat padaTabel 1.

Tabel 1. Rata-Rata Jumlah Korpus Luteum, Implantasi, Fetus Hidup,Fetus Mati dan Embrio Resorpsi Setiap Perlakuan

\begin{tabular}{lcccc}
\hline \multirow{2}{*}{ Jumlah Setiap Aspek Pengamatan } & \multicolumn{4}{c}{ PERLAKUAN } \\
\cline { 2 - 5 } & $\mathbf{A}$ & $\mathbf{B}$ & $\mathbf{C}$ & D \\
\hline Korpus Luteum (buah) & $9,83^{\mathrm{a}}$ & $7,33^{\mathrm{b}}$ & $9,33^{\mathrm{a}}$ & $10,83^{\mathrm{a}}$ \\
Implantasi (buah) & 9,17 & 4,50 & 6,50 & 6,16 \\
Fetus Hidup (individu) & $8,00^{\mathrm{a}}$ & $0,17^{\mathrm{b}}$ & $0,17^{\mathrm{b}}$ & $0,00^{\mathrm{b}}$ \\
Fetus Mati (individu) & $1,17^{\mathrm{b}}$ & $1,33^{\mathrm{b}}$ & $6,17^{\mathrm{a}}$ & $6,17^{\mathrm{a}}$ \\
Embrio Resorpsi (individu) & $0,0^{\mathrm{b}}$ & $3,0^{\mathrm{a}}$ & $0,0^{\mathrm{b}}$ & $0,0^{\mathrm{b}}$ \\
\hline Keterangan: Angka yang diikuti oleh huruf kecil berbeda, berbeda nyata pada taraf $\alpha 5^{\circ}$.
\end{tabular}

\section{PEMBAHASAN}

\section{Jumlah Korpus Luteum}

Ekstrak brotowali memperlihatkan pengaruh terhadap jumlah korpus luteum yang terbentuk pada ovarium tapi jumlah yang terbentuk masih dalam kisaran normal (Tabel 1). Rugh (1968) menyatakan bahwa rata-rata jumlah korpus Luteum mencit yang sudah matang reproduksinya umur 3-5 bulan yaitu 12,00 buah. Jumlah korpus luteum antara perlakuan C dan D dengan kelompok kontrol relatif sama, meskipun pada perlakuan B terlihat menurun bila dibandingkan dengan kontrol. Kondisi ini dikarenakan sifat genetis yang secara alami yang terdapat setiap individu induk mecit tersebut, jadi bukan karena pengaruh dari ekstrak brotowali. Korpus luteum merupakan cerminan jumlah dari ovum yang diovulasikan oleh suatu individu, dan kondisi ini akan tetap dipertahankan apabila terjadinya fertilisasi. Hal ini dikarenakan korpus luteum menghasilkan progesteron yang digunakan mempertahankan implantasi.

\section{Jumlah Implantasi}

Pemberian ekstrak brotowali berpengaruh tidak nyata terhadap jumlah implantasi embrio (Tabel 1). Dilihat secara angka-angka, pengaruh ekstrak brotowali cenderung menurunkan jumlah implantasi, karena dari semua perlakuan 
didapatkan jumlah implantasi sedikit dari kontrol. Tetapi hal ini masih dalam batas normal rata-rata jumlah implantasi mencit. Rugh (1968) menyatakan bahwa rata-rata jumlah implantasi mencit yang sudah matang reproduksinya umur 3-5 bulan yaitu 11,42 buah. Menurunnya jumlah implantasi pada perlakuan B, C, dan D pada umur kebuntingan 0 hingga 16 hari, disertai dengan meningkatnya kehilangan praimplantasi yang nyata lebih tinggi bila dibandingkan kontrol atau mungkin dikarenakan fertilisasi tidak terjadi. Proses fertilisasi ini adakalanya dapat mengalami gangguan akibat adanya pengaruh baik yang berasal dari internal maupun dari eksternal. Adanya berbagai zat-zat yang bersifat teratogenik dan fetotoksit yang masuk pada saat terjadinya proses fertilisasi akan menyebabkan fertilisasi tidak berlanjut. Senyawa- senyawa tersebut dapat berasal dari berbagai bahan seperti obat-obatan, ataupun berbagai bahan makanan yang terkonsumsi oleh maternal pada saat terjadi fertilisasi (Dixit, 1992). Proses fertilisasi ini adakalanya dapat mengalami gangguan akibat adanya pengaruh baik yang berasal dari internal maupun dari eksternal. Adanya berbagai zat-zat yang bersifat teratogenik dan fetotoksit yang masuk pada saat terjadinya proses fertilisasi akan menyebabkan fertilisasi tidak berlanjut. Senyawa-senyawa tersebut dapat berasal dari berbagai bahan seperti obat-obatan, ataupun berbagai bahan makanan yang terkonsumsi oleh maternal pada saat terjadi fertilisasi (Dixit, 1992)

Menurut Mansong dan Kang (1989), implantasi mencit berlangsung pada umur kebuntingan 4 atau 5 hari. Karena pemberian ekstrak brotowali pada induk mencit umur kebuntingan 0 hingga 16 hari yang selama kebuntingan tersebut mengganggu perkembangan embrio praimplantasi, maka pada periode praimplantasi tersebut mungkin banyak jumlah embrio yang tidak mencapai tahap blastosista sehingga tidak dapat implantasi. Hal ini mungkin kandungan senyawa aktif yang terdapat di dalam brotowali mengganggu proliferasi sel-sel embrional yang terjadi pada tahap cleavage dari embriogenesis.

\section{Jumlah Fetus Hidup dan Mati}

Pemberian ekstrak brotowali berpengaruh nyata terhadap jumlah rata-rata fetus hidup dan mati (Tabel 1). Dimana pengaruh ekstrak cenderung menurunkan jumlah fetus hidup dan meningkatkan jumlah fetus mati. Hal ini mungkin 
disebabkan karena ekstrak brotowali mengandung saponin yang memiliki efek negatif pada reproduksi hewan, yaitu sebagai abortivum, menghambat pembentukan zigot dan anti implantasi (de Padua,1978 dalam Rusmiati, 2010). Saponin bersifat sitotoksik terhadap sel terutama yang sedang mengalami perkembangan, seperti pada saat oogenesis (Nurhuda dkk.,1995 dalam Nurliani, 2007).

Penurunan jumlah fetus hidup dan peningkatan jumlah fetus mati mungkin juga disebabkan oleh senyawa alkaloid yang dikandung ekstrak brotowali selain memperlihat sifat antiproliferasi juga memiliki sifat embriotoksit dan teratogenik, seperti yang dilaporkan Sabri (2007) alkaloid dapat menyebabkan meningkatnya kehilangan praimplantasi secara nyata, jumlah implantasi dan jumlah fetus hidup menurun secara nyata serta bersifat antifertilitas.

\section{Jumlah Embrio Resorpsi}

Dari Tabel 1 dapat dilihat pemberian ekstrak brotowali berpengaruh nyata terhadap embrio resorpsi. Dimana pengaruh perlakuan B berbeda dengan kontrol, perlakuan C dan D. Hal ini dikarenakan pemberian ekstrak brotowali yang berlangsung mulai tahap praimplantasi hingga organogenesis, sehingga induk tidak mampu mendetoksifikasi senyawa aktif yang terdapat dalam brotowali akibatnya zat aktif yang terdapat di dalam ekstrak brotowali tidak dapat dieliminasi dan akan terbawa di dalam pembuluh darah dan selanjutnya akan mempengaruhi proses perkembangan embrio. Oleh karena itu emberio pada tahap cleavage tidak mampu mencapai tahap blastosista yang sempurna, dengan demikian embrio tidak mampu implantasi atau perkembangan tidak sempurna sehingga diresorpsi. Seperti yang dikemukakan oleh Manson dan Kang (1989) serta Jacobsons (1995) bahwa embrio yang berada pada periode praimplantasi lebih rentan terhadap kematian oleh adanya xenobiatik. Selanjutnya Syahrum dan Kamaludin (1994) senyawa yang bersifat toksik akan mempengaruhi sel-sel mensenkim sehingga proliferasi embrio terganggu. 


\section{SIMPULAN}

Pemberian ekstrak brotowali secara oral pada umur kebuntingan 0-16 hari cenderung menurunkan jumlah korpus luteum, jumlah fetus hidup, jumlah fetus mati dan embrio resorpsi serta tidak berpengaruh nyata terhadap implantasi.

\section{DAFTAR PUSTAKA}

Adnan. 1992. Pengaruh Mangostin Terhadap Fungsi Reproduksi Mencit (Mus musculus L. Swiss Webster) Betina. Tesis Pascasarjana Biologi. ITB. Bandung.

Akbar, B. 2010. Tumbuhan dengan Kandungan Senyawa Aktif yang Berpotensi Sebagai Bahan Anti Fertilitas. Adabia Press. Jakarta.

Nurliani, A. (2007). Penelusuran Potensi Antifertilitas Kulit Kayu Durian (Durio zibethinus Murr) Melalui Skrining Fitokimia. Jurnal Sains dan Terapan Kimia.1(2). Hlmn. 53-58.

Chantong, B. Kampeera, T. Sirimanapong W.2008. An-tioxidant activity and cytotoxicity of plants commonly used in veterinary medicine. Acta Hort (ISHS)

Chattopadhyay, S. et.al. 1994. Effect of Mongiferin a Naturally Occuring Glucosylxanthous on Reproductive Function of Rat. Journal Pharmaceut Sci. 41. P.274-282

Dixit, VP. 1992. Plant Product non Streroid Compound affecting Fertility in the Indian Desert Gerbil, Meriones Hurricane. Rodents in Indian Agriculture. 1: 595-604. Driancourt, M. A., A. Gougeon, Royere, A dan C.

Dweck, A.C, Cavin, J.-P., 2006. A review of Andawali (Tinospora crispa). Personal Care Magazine 7, 1-3, Available at: www.dweckdata.com/published papers/Tinospora crispa.pdf.

Erlina, R. 1981. Pengaruh Perasan Buah Nenas Muda (Ananas comosus Merr.) Terhadap Daur Estrus Mencit. Tesis Sarjana Farmasi. FMIPA Universitas Andalas. Padang.

Farnsworth, NR. et al. 1975. Potential Value of Plants as Sources of New Antifertility Agent. Journal Pharmaceut Sci. 64. P. 535-588.

Gordon, J.D. dan Sperof L. 2003. Hand Book For Clinical Gynecologic, Endocrynology, and Fertility. Lippincott Williams \& Wilkins :Philadelphia

Greenspan, F.C, Baxter, J.D. 1994. Basic and Clinical Endocrinology. University of California: San Fransisco.

Isnaeni, W. 2006. Fisiologi Hewan. Kanisius : Yogyakarta.

Jacobsons. M. 1995. Antifertility Effects and Population Controls Agents. VCH Verlagsgesell Schaft, Weinheim Germany.

Kresnady, 2003, Khasiat dan Manfaat Brotowali Si Pahit yang Menyembuhkan. Media Pustaka: Tangerang.

Manson, J. M. \& Kang, Y. J., 1989. Methods For Assesing Female Reproductive and Develompment Toxicology In Principles and Methods Of Toxicology. Second Edition. A.W Hayes Raven Press, Ltd. New York. Page. 321. 
Nalbandov, A.V. 1990. Fisiologi Reproduksi Mamalia dan Unggas. Penerjemah Keman S. UI Press: Jakarta.

Palupi, J.2008. Pengaruh Pemberian Ekstrak Kulit Buah Manggis (Garcinia mangostana L.) Per Oral Terhadap Folikulogenesis Ovarium Mencit (Mus musculus). Jurnal Kesehatan, Vol. 6 No 2. Diakses 12 Desember 2012

Rugh, R. 1968. The Mouse Its Reproduction and Development. Burgess Publishing Company: Minneapolis.

Rusmiati. 2010. Pengaruh Ekstrak Metanol Kulit Kayu Durian (Duria zibethinus Murr) pada Struktur Mikroanatomi Ovarium dan Uterus Mencit (Mus musculus) Betina. Jurnal Sains dan Terapan Kimia. 4(1). Hlmn. 29-37.

Sabri, E. 2007. Efek Perlakuan Ekstrak Andaliman (Zanthoxyllum acanthopodium) pada Tahap Praimplantasi terhadap Fertilitas dan Perkembangan Embrio Mencit (Mus musculus). Jurnal Biologi Sumatera. Vol 2,(2). Hal 28-32.

Smith, B.J dan S. Mangkoewidjojo. 1988. Pemeliharaan, Pembiakan dan Penggunaan Hewan Percobaan di Daerah Tropis. UI Press : Jakarta.

Sumarmin, R. 2001. Uji In Vivo Ekstrak kulit Batang Angsana (Pterocarpus indicus W.) terhadap Fertilitas Mencit Betina (Mus musculus L. Swiss Webster). Laporan Hasil Penelitian Proyek Pengembangan Diri. FMIPA Universitas Negeri Padang.

Supriadi. 2001. Kandungan Brotowali (Tinospora crispa). Fakultas Kedokteran Universitas Indonesia: Jakarta.

Syahrum, M.H dan Kamaludin, 1994. Reproduksi dan Embriologi : Dari Satu Sel menjadi Organisme. Fakultas Kedokteran Universitas Indonesia : Jakarta.

Toelihere, MR. 1979. Fisiologi Reproduksi pada Ternak. Angkasa : Bandung.

Taylor, P. 1994. Practical Teratology. WB Saunders Co: London.

Widiana, R dan R. Sumarmin. 2014. Pengaruh Ekstrak Brotowali (Tinospora crispa L.) Terhadap Siklus Reproduksi dan Karakter Morfologi Ovarium Mencit (Mus musculus L.). Laporan Penelitian, Dana Hibah Bersaing Yayasan Pendidikan PGRI Padang Sumatera Barat. Padang

Wurlina, 2003. Efek Alkaloid dan Achyranthes aspera Linn. Terhadap Perkembangan Sel Embrio (Cleavage) Mencit (Mus culinus). Research Center of Traditional Medicine Airlangga University. Jipunair-gdl-res. Surabaya

Yatim, W. 1984. Embriologi Untuk Mahasiswa Biologi dan Kedokteran Edisi III. Tarsito: Bandung. 